ПРОБЛЕМА ПРАВОВОГО ОБЕСПЕЧЕНИЯ СОЦИАЛЬНОЙ РАБОТЫ С НЕСОВЕРШЕННОЛЕТНИМИ МАТЕРЯМИ (НА ПРИМЕРЕ ВОЛГОГРАДСКОЙ ОБЛАСТИ)

Захарова Анастасия Олеговна

Волгоградский государственный университет (400062, г. Волгоград, пр-т Университетский 100)

Аннотация. Несовершеннолетнее материнство представляет собой вполне распространенное социальное явление, не только в России, но и во всем мире. Проблема юного материнства в последние десятилетия приобрела большую актуальность в связи с многочисленными факторами: снижением возраста сексуального дебюта, с ростом сексуальной активности подростков, их низкой контрацептивной культурой, возрастанием количества беременностей и родов девушек до 18 лет. Вместе с тем, правовое обеспечение социальной работы с несовершеннолетними матерями, их родительскими семьями и социальным окружением в России находится все еще на стадии своего становления, о чем свидетельствует тот факт, что сегодня, юные мамы не выделяются в отдельную категорию социально незащищенных, для них не предусмотрены дополнительные выплаты, или социальные пособия и это делает положение юных мам в Российской Федерации катастрофическим, которое таит в себе кучу негативных последствий. Со стороны государства они получают некоторые виды помощи, которые, к своему сожалению, недостаточны. Юные матери ввиду своего положения экономически зависимы от своих родителей, ближайшего окружения и нуждаются в помощи квалифицированных специалистов социальной сферы, а не только семьи, родственников и близких. Ключевые слова: несовершеннолетнее материнство, сексуальный дебют, социальная помощь, пособия. 


\section{THE PROBLEM OF LEGAL SUPPORT OF SOCIAL WORK WITH MINOR MOTHERS (ON THE EXAMPLE OF THE VOLGOGRAD REGION)}

\section{Zakharova Anastasia Olegovna}

Volgograd State University (400062, г. Волгоград, пр-т Университетский 100)

Resume. Minor maternity is a very common social phenomenon, not only in Russia, but throughout the world. The problem of young motherhood in recent decades has acquired great relevance due to many factors: a decrease in the age of sexual debut, with the growth of sexual activity among adolescents, their low contraceptive culture, an increase in the number of pregnancies and childbirth of girls under 18. At the same time, social work with underage mothers, their parents' families and social environment in Russia is still at the stage of its formation, as evidenced by the fact that today, young mothers do not stand out as a separate category of socially unprotected, they do not have additional payments, or social benefits, and this makes the situation of young mothers in the Russian Federation catastrophic, which carries a lot of negative consequences. From the state side, they receive some types of assistance, which, unfortunately, are not enough. Young mothers, because of their position, are economically dependent on their parents and close associates and need the help of qualified specialists in the social sphere, and not just families, relatives and close ones.

Key words: underage maternity, sexual debut, social assistance, benefits.

Исследование проблем семьи находится в центре внимания многих наук, так как она является институтом первичной социализации человека, жизнедеятельности личности, важнейшим элементом его самоорганизации. Актуальность исследования растет в условиях экономического кризиса и социально-политических преобразований в стране, а также когда проявляются негативные последствия демографических потерь населения. Текущие процессы привели к искожению внутрисемейных связей, разрыву межпоколенных отношений, увеличению числа разводов, бездетности, внебрачной рождаемости, социальному сиротству, что свидетельствует о серьезных сбоях в механизме реализации основных функций семьи. Не редкостью стало такое социальное явление как несовершеннолетнее материнство По данным статистики, до $10 \%$ девочек начинают половую жизнь в возрасте до 14 лет. Ежегодно в РФ имеет место около 1,5 тысяч рождений у матерей в возрасте 15 лет, 9 тысяч - 16 лет, 30 тысяч - в возрасте 17 лет. 
Фактически удельный вес детей, рожденных женщинами моложе 18 лет, в общем числе родившихся составляет в среднем 2,3\%. [4]. Буквально каждый пятый ребенок рождается у матери, не достигшей возраста 18 лет. Эти цифры подчеркивают всю серьезность проблемы подростковой беременности и юного материнства.

В России охрана и защита прав и интересов юных матерей осуществляется через государственные органы и учреждения, которые грамотны в сфере охраны и защиты прав и свобод человека. Они проводят мероприятия, направленные на улучшение правового статуса малолетних матерей, работающих матерей, одиноких родителей, воспитывающих детей, многодетных семей и других. Однако, несмотря на проводимую политику, желаемые результаты не будут достигнуты до тех пор, пока малолетние мамы не будут выделены в отдельную категорию социально-незащищенных граждан и не получат официальный статус, пока не станут объектом специального внимания со стороны государства.

В настоящее время социальная политика в отношении российских семей активно развивает систему предоставления льгот, пособий, субсидий. Это позволяет лишь поддерживать минимальный уровень жизни малолетних матерей. Но она не решает главной задачи - создание условий для их достойной жизни, равенства возможностей молодых родителей.

Правовое регулирование отношений в сфере предоставления мер социальной поддержки и социальной помощи в Волгоградской области осуществляется на основании Конституции Российской Федерации, федеральных законов и иных нормативных правовых актов Российской Федерации, Социального Кодекса Волгоградской области, законов и иных нормативных правовых актов Волгоградской области. Опираясь на региональное законодательство, можно выделить следующие выплаты, которые положены всем женщинам, родившим на территории Волгоградской области (в том числе несовершеннолетним матерям) [9]: единовременное пособие женщинам, вставшим на учет в ранние сроки беременности (до 12 
недель) - 581 руб. ;единовременное пособие при рождении ребенка (региональная надбавка к федеральной выплате) - 17 тыс. руб. + федеральная выплата 15 тыс. руб.;ежемесячное пособие по уходу за ребенком (до полутора лет) составляет $40 \%$ от среднего заработка, минимум - 2900 руб. (на одного ребенка) и 5800 руб. на второго и последующих детей; ежемесячное пособие на ребенка (для малоимущих семей) разнится в зависимости от категории малоимущей семьи, что отражено в таблице 1.

Таблица 1 - размер ежемесячных пособий на детей для малоимущих семей в 2017 г. (в том числе несовершеннолетних матерей, относящихся к данной категории)

\begin{tabular}{|l|l|}
\hline Категории малоимущих семей & Размер выплаты \\
\hline Обычный размер выплаты & 317 руб. \\
\hline Одинокий отец (мать) & 634 руб. \\
\hline Студенческая семья & 1000 руб. \\
\hline $\begin{array}{l}\text { Многодетная малоимущая семья, имеющая в своем } \\
\text { составе 3 и более несовершенолетних детей }\end{array}$ & 555 руб. \\
\hline $\begin{array}{l}\text { Малоимущие семьи, в которых один из родителей } \\
\text { уклоняется от уплаты алиментов }\end{array}$ & 476 руб. \\
\hline $\begin{array}{l}\text { Малоимущие семьи, в которых родители (родитель) } \\
\text { проходят военную службу по призыву }\end{array}$ & 476 руб. \\
\hline
\end{tabular}

Кроме того, с 1 января 2017 г. в Социальном Кодексе Волгоградской области вступили в силу изменения, согласно которым осуществляется дополнительная социальная поддержка молодых родителей. Так, например, в регионе выплачивается дополнительная единовременная выплата при рождении первого ребенка женщинами в возрасте до 23 лет - 25 тыс. руб. [3] , вне зависимости от уровня доходов. Положительным является и тот факт, что значимость рождения первого ребенка в семье отмечается и на уровне государства, а именно, тот факт, что семьи, в которых первый ребенок родится после 1 января 2018 г. будут получать ежемесячное пособие в размере 10 тыс. 500 руб. [7]. 
К числу социально-экономических видов помощи несовершеннолетним матерям, в частности, одиноким несовершеннолетним матерям, следует отнести алименты. Так, ст. 54 СК гарантирует детям право жизни и воспитания в семье; право знать своих родителей (если это не противоречит правилам); право на заботу со стороны родителей и др.[10, ст. 54]. Родители, в свою очередь, наделены равнозначными родительскими правами и обязанностями по отношению к своим детям. Так, например, в ст. 62-64 СК РФ указывается то, что родители имеют право и обязаны воспитывать своих детей, защищать их права до наступления ими совершеннолетнего возраста [10, ст. 62 - 64]. После расторжения брака родители обязаны содержать своих несовершеннолетних детей. Поэтому родитель, оставивший семью, должен выплачивать своим детям алименты (ст. 81 СК РФ) [10, ст. 81]. Необходимо отметить тот факт, что уплата алиментов родителем обязательна, независимо от того, является ли родитель дееспособными или недееспособными, трудоспособными или нетрудоспособными, совершеннолетними или несовершеннолетними, а также независимо от того, каково материальное положение детей. Ст. 157 УК РФ №63-Ф3 от 13.06.1996 г. гласит о том, что в связи со злостным уклонением от уплаты по решению суда алиментов своим несовершеннолетним детям, суд наказывает родителя обязательными работами на срок от 120 до 180 часов, либо исправительными работами на срок до одного года, либо арестом на срок до трех месяцев [11].

Федеральный закон ред. от 19.05.1995г. «О государственных пособиях гражданам, имеющим детей» гласит, что матери-одиночки, в частности, несовершеннолетние матери, воспитывающие детей в одиночку, имеют право на определенные льготы: в связи с ростом цен на продукты питания, матьодиночка имеет право на компенсацию повышающейся стоимости продуктов, предназначенных для ребенка, не достигшего $3 \mathrm{x}$ лет; при рождении ребенка и до достижения им возраста 3 лет, оказывается натуральная помощь; предусмотрены бесплатные комплекты детского белья для детей, родившихся вне брака; при рождении ребенка и до достижения им возраста двух лет, 
родитель имеет право на бесплатное детское, молочное питание, выдаваемое по рецептам врачей в лечебных учреждениях; бесплатными медицинскими препаратами обеспечиваются дети из неполных семей, не достигшие 3 лет; при достижении школьного возраста, дети матерей-одиночек обеспечиваются бесплатным двух разовым питанием в школьной столовой; дети матерейодиночек, получают льготы при оплате за обучение в школах искусств, стоимость оплаты ниже обычной стоимости на $30 \%$ [6, с. 130].

Необходимо отметить федеральную целевую программу «Жилище», которая стартовала впервые в 2002 г., а в 2015 году была второй раз продлена до 2020 года [8]. Хочется отметить, что несовершеннолетние матери могут в ней участвовать, если они признаются нуждающимися в улучшении жилищных условий (либо отсутствие собственного жилья, либо его малая площадь из расчета 11 квадратных метров на члена семьи). Конкретно для несовершеннолетних матерей данная программа не является эффективной, исходя из того положения, что размер предоставляемой по программе субсидии не превышает 30\% от стоимости жилья. Вместе с тем, субсидию можно использовать только на приобретение квартиры в новом доме, или вступив в долю при строительстве нового жилья, но нельзя потратить на приобретение вторичного жилья, поэтому обязательным документом к рассмотрению для участия в программе является справка о доходах, для того чтобы оценить возможность семьи в выплате ипотечного кредита. Таким образом, программа ориентирована на молодые семьи с постоянным и высоким уровнем дохода, которые в состоянии ежемесячно выплачивать платежи по ипотеке. Как мы знаем, несовершеннолетние матери с детьми ввиду своего специфического положения, не располагают высокими доходами.

Напрашивается вывод о том, что многие гарантии для несовершеннолетних матерей остаются лишь только на бумаге. Несмотря на некоторые положительные изменения, в целом же, примерно во всех регионах ситуация идентичная, в большинстве случаев, ежемесячные выплаты родителям с детьми не превышают прожиточного минимума, что крайне негативно 
сказывается на жизни малолетней мамы и еe ребенка. Как мы видим, государственная помощь экономического характера конкретно несовершеннолетним матерям не предоставляется и программ таковых на территории РФ нет. Выплаты и пособия юным мамам прописываются в законах о многодетных и молодых семьях, в которых ставится акцент на поддержку семей с детьми. Вместе с тем, несовершеннолетняя мать зачастую не знает о своих правах в области социальной поддержки, это обусловлено низкой информированностью в связи с юным возрастом и, в связи с тем, что социальные службы не предоставляют открыто информацию о социальных гарантиях. Еще одной важной проблемой органов социальной защиты является недостаточное финансирование социальной сферы, под которой подразумевается увеличение государственных ассигнований, ведь по оценкам экспертов, выделяемые пособия на детей в таких семьях, улучшают их доход лишь на $3 \%$ [6, с. 131$]$.

Таким образом, главная проблема в оказании социальной помощи несовершеннолетним матерям заключается в отсутствии законодательного закрепления данной категории, в связи с чем, государством не предусмотрены специальные дополнительные выплаты и помощь иного характера для юных матерей, что, безусловно, негативно сказывается на их жизнедеятельности.

\section{Список литературы}

1. Андрющенко, О.Е. Проблемы кодификации социально-обеспечительного законодательства (на примере Волгоградской области) / О.Е. Андрющенко // Социальное и пенсионное право. - 2016. - № 2. - С. 42-46.

2. Андрющенко О.Е. Социальная защита несовершеннолетних матерей на современном этапе: региональный аспект (на примере Волгоградской области) / О.Е. Андрющенко, Т.А. Гладилина // Международный студенческий научный вестник. 2018. № 1. С. 107. 
3. Вести 24 Волгоград: С 1 января вступят в силу изменения в Волгоградском Социальном Кодексе / Электрон. Pecypc URL: http://www.volgograd-trv.ru/news.aspx?id=37940 (дата обращения 24.05.2018)

4. Васильев Т.В. Болезнь-расплата / А.В Васильев - М.: Феникс, 2011. - С. 369.

5. Кантемирова Г. А. Социальная защита неполных семей в контексте государственной семейной политики / Г.А Кантемиров. Общественные науки. - 2011. - №3. -C. 229 - 231.

6. Нелидкин, А.М., Терешкин Н.С. Малолетнее материнство: проблемы и пути решения / А.М. Нелидкин, Н.С. Терешкина. Межвузовский сборник научных трудов. - 2015. - №1. - С. 127 - 132.

7. Пособие на первого ребенка с 2018 года : Электрон. дан., дата обращения: 15.06.2018.

8. Постановление Правительства Российской Федерации от 17.12.2010 № 1050 «О Федеральной целевой программе «Жилище» на 2011-2015 годы» // Собрание законодательства Российской Федерации. 2015. № 5. Ст. 2204.

9. Размер детских пособий в Волгоградской области в 2017 году / Электрон. Pecypc. URL: http://setdoc.ru/regions/volgograd/ (дата обращения 15.06.2018).

10. Семейный Кодекс РФ от 29.12.1995 №223-Ф3 // Рос. Газ. 1996. №17 : 2015. №85.

11. Уголовный кодекс Российской Федерации от 13.06.1996 г. № 63-Ф3 // Собрание законодательства РФ. 1996. № 25. 